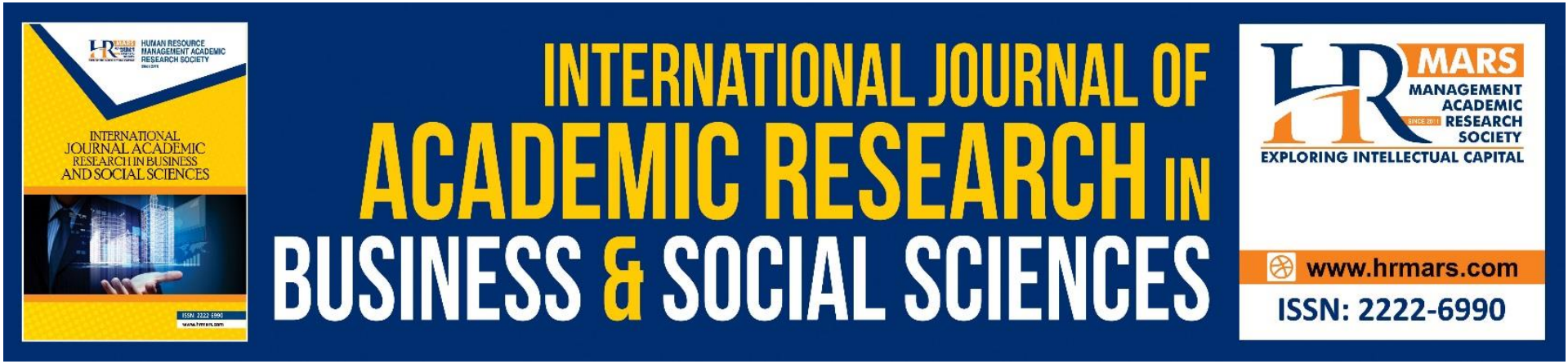

\title{
Maqasid Shariah as A Paradigm in the Implementation of Financial Assistance in Malaysia
}

Ahmad Nazrul Alif Yahya, Wan Norhaniza Wan Hasan, Farhat Nazirul Mubin Bohari

To Link this Article: http://dx.doi.org/10.6007/IJARBSS/v11-i11/11561

DOI:10.6007/IJARBSS/v11-i11/11561

Received: 04 September 2021, Revised: 10 October 2021, Accepted: 21 October 2021

Published Online: 06 November 2021

In-Text Citation: (Yahya et al., 2021)

To Cite this Article: Yahya, A. N. A., Hasan, W. N. W., \& Bohari, F. N. M. (2021). Maqasid Shariah as A Paradigm in the Implementation of Financial Assistance in Malaysia. International Journal of Academic Research in Business and Social Sciences, 11(11), 633-643.

Copyright: (c) 2021 The Author(s)

Published by Human Resource Management Academic Research Society (www.hrmars.com)

This article is published under the Creative Commons Attribution (CC BY 4.0) license. Anyone may reproduce, distribute, translate and create derivative works of this article (for both commercial and non-commercial purposes), subject to full attribution to the original publication and authors. The full terms of this license may be seen at: http://creativecommons.org/licences/by/4.0/legalcode

Vol. 11, No. 11, 2021, Pg. $633-643$

Full Terms \& Conditions of access and use can be found at http://hrmars.com/index.php/pages/detail/publication-ethics 


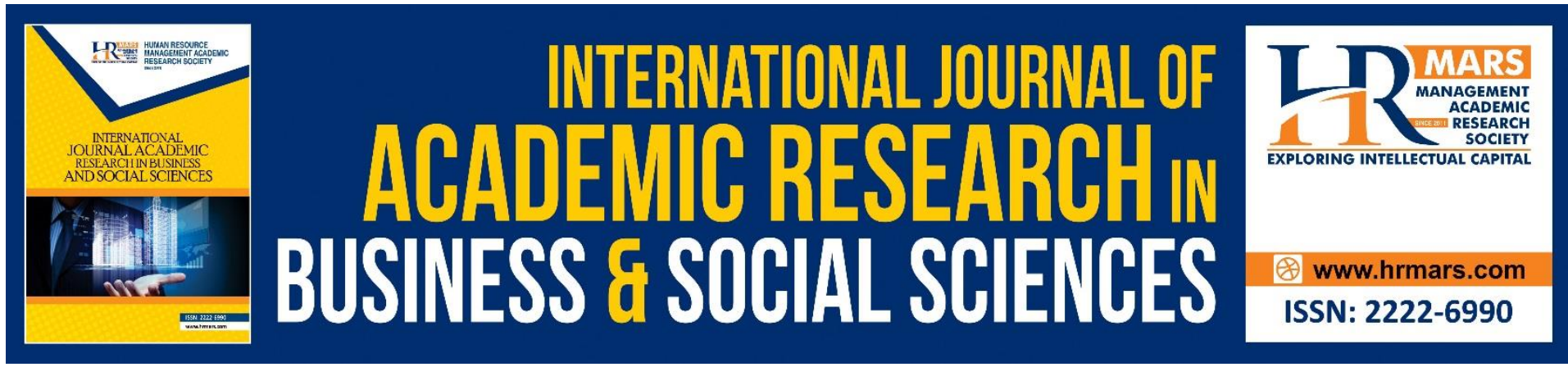

\title{
Maqasid Shariah as A Paradigm in the Implementation of Financial Assistance in Malaysia
}

\author{
Ahmad Nazrul Alif Yahya, Wan Norhaniza Wan Hasan, Farhat \\ Nazirul Mubin Bohari \\ Centre for Islamic Development Management Studies (ISDEV) Universiti Sains Malaysia
}

\begin{abstract}
This paper aims to analyze the maqasid shariah as a paradigm in the implementation of financial assistance in Malaysia. Financial assistance is generally intended to meet the needs of the low-income group in handling the rising cost of living. The rising cost of living along with a country's development and progress has caused developed and developing countries to implement assistance package to the citizen based on the needs of their own people. The question is, does the maqasid shariah exist as a paradigm in the implementation of the financial assistance? This paper has two objectives. Firstly, to identify the paradigm of maqasid shariah. Secondly, to analyze the maqasid shariah as a paradigm in the implementation of financial assistance in Malaysia. The content analysis method was used to conduct the research. Maqasid shariah as a paradigm in the implementation of financial assistance in Malaysia is important to ensure that the assistance can meet the benefits and benefits to all parties.
\end{abstract}

Keywords: Maqasid Shariah, Assistance, Financial, Malaysia

\section{Introduction}

Financial assistance is a form of assistance provided by the government to the underprivileged in facing current financial challenges. In Malaysia, financial assistance is channelled at the national level by the central government through application and evaluation mechanisms. Apart from the central government, financial assistance is also provided by the state government and various government agencies, both central and state. At the federal level, financial assistance is channelled to recipients through the management of a designated ministry. Usually, financial assistance is distributed to focused groups to help them in living their lives. In addition, financial assistance is also intended to assist in overcoming the rising cost of living of the low-income group. This method is seen as one of the measures in balancing the government's decision to rationalize subsidies of various household needs (EPU, 2015).

Most of the financial assistance is given to the eligible groups based on the rules made by the government and certain ministries for the assistance distribution. The method of channelling financial assistance by the government is one of the important aspects of Islamic economics 
which emphasizes that the wealth of a country is distributed comprehensively as said by Allah SWT in al-Quran on the surah of al-Hasyr, verse 7 which means: "So that the wealth does not just circulate among the rich among you".

Through this distribution, justice can be implemented and open up space for society to live together in harmony at the same time. Islam calls on its people to progress forward in all aspects of life, including in the development of the Islamic economy. The thought of Islamic economic development outlined by al-Qur'an and al-Sunnah are material and spiritual in nature, encompassing not only the economic development itself, but also human, social and other development. In other words, the development of the Islamic economy is syumul (holistic) and with the aim of falah (success) for the construction of a society with high level of tawheed and civilised.

\section{Research Methodology}

This qualitative study collected secondary data from the literatures related to the scope of the study. Secondary data are the existing data collected and processed by previous researchers (David \& Sutton, 2011; Bowen, 2009; Hennink et al., 2010; Tracy, 2013). It involves the examination of any form of writing whether in the form of text or numbers obtained through the study of written documents. The referred documents in this study including textual materials on financial assistance that has been implemented in Malaysia as well as written materials related to the maqasid shariah. Documents collected for this process including official reports, journal articles through online databases and published papers. The findings were then analysed through content analysis method by categorizing the findings in themes that formed based on the information collected.

\section{Financial Assistance in Malaysia}

Various assistance to the target group has been implemented in Malaysia from various parties whether government or non -government, including the national level or at the state level. These assistances are not limited to assistance in financial form but there are also in other forms such as housing assistance, school assistance, health assistance and so on. In general, the assistance provided is aimed at helping the less fortunate. The less fortunate status happened due to several factors such as rising cost of living, geographical location and poverty. In addition, aid distribution is also a form of wealth redistribution.

Among the financial assistances that have been implemented in Malaysia including 1Malaysia Financial Assistance for People or "Bantuan Rakyat 1 Malaysia" (BR1M), Child Assistance Scheme, State Government Financial Assistance, Assistance for the Disabled, Financial Assistance for the Elderly, Child Care Assistance for the Low-Income Group and Business Assistance. These financial assistances were implemented by the government agencies such as the Department of Social Welfare, State Government Assistance Scheme, Assistance Allocation by the Federal Government, Ministry of Rural Development and others.

Each financial assistance has its own terms and conditions. The parties that implement it have submitted various ways of application and evaluation for financial assistance so that it can be channelled to the right people. For example, assistance through the Department of Social Welfare (Jabatan Kebajikan Masyarakat, JKM) focuses on women or single mothers, people with disabilities (PWD) and also the elderly as recipients of assistance. Usually, the assistance 
provided by JKM is given continuously every month to the recipient with a value between RM150 to RM450 based on certain conditions (JKM, 2021).

The main purpose of financial assistance is to temporarily ease the burden of individuals and families and to encourage the target group who are still productive to return to work and to be able to be independent. For example, the child assistance scheme was introduced by JKM to help poor children to ensure that the children live with their families and through the development of their lives better. Child assistance is given at RM100 for each child and a maximum of RM450 for families with more than 4 children. This assistance not only can help and ease the burden of families but also able to prevent the dropout of children of poor families from the school system. Specifically, JKM (2021) listed three main purposes of their financial assistance scheme which are:

- As an income maintenance for the poor and needy family to fulfil their basic needs.

- To encourage the productive target groups to work and live independently.

- To improve the quality of life of target groups for a better living.

Apart from financial assistance through JKM, an assistance scheme provided as a one-off allocation was introduced in 2012 with BR1M. The branding of financial assistance was implemented until 2018 and has shown positive development in addressing the cost of living of the people with increasing value of assistance each year with total expenditure between 2.9 billion to 6.3 billion (MOF, 2018). This assistance focuses on the low-income group.

BR1M was introduced with the aim of helping to ease the burden of rising cost of living among the bottom 40 per cent group known as the B40 group. This group is seen as a group that is vulnerable to economic risk (EPU, 2015). BR1M is one of the assistance initiatives implemented under the Government Transformation Program introduced by the 7th Prime Minister of Malaysia in December 2011. The BR1M distribution mechanism was initially done using tax revenue collected by the Inland Revenue Board of Malaysia (Lembaga Hasil Dalam Negeri, LHDN). A total of RM26 millions of tax revenue is used for this purpose (PEMANDU, 2012). BR1M has benefited 4.7 million households and 2.7 million single individuals from across Malaysia. For the beginning of BR1M distribution, the payment policy was one off for households with earning of RM3,000 and below, while single individuals aged 21 and above with income not exceeding RM2,000 per month with BR1M assistance value of RM250 per individual (PEMANDU, 2012). This financial assistance was implemented from 2012 to 2018. Through BR1M, the government has distributed the amount of assistance between RM 500 to RM1200 throughout its implementation.

Financial assistance with a similar purpose and mechanism is implemented in 2019 with a new financial assistance scheme name known as Subsistence Assistance (Bantuan Sara Hidup, $\mathrm{BSH})$. Like BR1M, BSH is also implemented and managed by the Ministry of Finance Malaysia using almost the same mechanism with different branding.

In addition, the Government was also implemented the economic stimulus package in order to help the needy to ease the burden of the citizen. The 8th Prime Minister of Malaysia introduced the "Prihatin Rakyat Economic Stimulus Package" (PRIHATIN) aimed at easing the burden of the people in facing the Covid-19 epidemic. The government has prepared the National Prihatin Assistance (Bantuan Prihatin Nasional, BPN) which is a one-off cash grant 
with an allocation of almost RM10 billion. This assistance is given to private employees, FELDA settlers, farmers, fishermen, small traders and all those who belong to the M40 group and below. In addition, in June 2020, the 8th Prime Minister of Malaysia introduced the National Economic Regeneration Plan (Pelan Jana Semula Ekonomi Negara, PENJANA) which aims to empower the people, boost business and stimulate the national economy. Overall, there are 40 initiatives worth RM 35 billion under PENJANA.

For the year 2021, the Government will replace Subsistence Assistance (BSH) with Prihatin Rakyat Assistance (BPR) with better assistance rates and income categories. In 2021, the BPR is distributed to several categories. Firstly, households with monthly income of less than MYR 2,500 and having up to one child will receive assistance of MYR 1,200, while households with two or more children will receive assistance of MYR 1,800. Secondly, for households with monthly income between MYR 2,501 to MYR 4,000 with up to one child, BPR assistance of MYR 800 will be channelled, while households with two or more children will receive assistance of MYR 1,200. Thirdly, the government will also help households with monthly income of between MYR 4,001 to MYR 5,000. This category will receive MYR 500 ringgit for those with up to one child and MYR 750 assistance to households with two or more children. Fourthly, single individuals with income of MYR 2,500 and below, will receive assistance of MYR 350. Not only that, the age limit for single individuals has been lowered to 21 years, compared to the previous condition, which was 40 years. Overall, the BPR grant is expected to benefit 8.1 million people with allocation of 6.5 billion ringgit compared to 4.3 million recipients and allocation of 5 billion ringgit previously under $\mathrm{BSH}$.

The implementation of financial assistance by the Government each year has allocated a high amount of distribution for such assistance, which is more than RM10 billion. All the purposes of financial assistance discussed above have a common purpose which are to eradicate poverty, improve the citizen's economy and improve the living standards of low-income groups in line with the rising cost of living today and also the impact of the Covid-19 pandemic. The effectiveness of this financial assistance should be continued by various parties so that it can help those in need.

\section{Maqasid Shariah}

Linguistically, maqasid shariah consists of two words, namely, maqasid and shariah. Maqasid is the plural form of maqsid which means intentional or purposeful, shariah means path to the source of water. The road to this water source can also be said to be the road to the main source of life. According to Al-Syatibi, the maqasid of shariah is the purpose or objective of shariah which pays more attention to the public interest. As found in dictionary and its explanation that the shariah is a law prescribed by Allah for His servants on religious matters, or, a law prescribed and commanded by Allah in the form of ibadah (fasting, prayer, pilgrimage, zakat, and all good deeds) or muamalah that drives human life (selling, buying, marrying, etc.).

Islam has the holy book of the al-Quran. As the main source of reference, the al-Quran contains various teachings. The content of the al-Quran can be categorised into three main groups, namely, aqidah, khuluqiyyah, and amaliyah. Aqidah is related to the fundamentals of faith. Khuluqiyyah deals with ethics and morals. Amaliyah discusses the aspects of law that come out of aqwal (expression), and af'al (human action). Prior to this, the shariah was al- 
nusus al-Muqaddas from the al-Quran and the sunnah of mutawatir which was not disturbed by human thought. In a shariah-like form, it is called al-tariwah al-mustaqimah. The content of shariah in this sense includes aqidah, amaliyah, and khuluqiyyah. According to the terminology, maqasid shariah is the content of values that become the purpose to the law. Hence, maqasid shariah is the goal that must be achieved from the determination of the law.

\section{Maqasid Shariah Categories}

Al-Qardhawi (1996); Naim (2003) quoted arguments by al-Syathibi on the main purpose of maqasid shariah whisch is to defend and strive for three categories of law, namely:

\section{a. Daruriyyat}

Literally, it means an urgent or emergency need. In this category there are five things to consider, namely; preserving religion; preserving the soul; preserving the intellect; preserving honour and lineage; and preserving property. In the need of daruriyyat, if this level of need is not met, it will threaten the safety of mankind in this world and the hereafter. There are five main and basic things included in this type, which the importance should always be taken care of or protected:

- Protecting the Religion (al-Din)-for individuals ad-Din related to worship performed by a Muslim and Muslimah, defending Islam from false teachings, defending Islam from attacks by people who believe in other religions

- Protecting Life (al-Nafs) - In Islam, human life is something very precious and must be taken care of and protected. A Muslim is forbidden to kill others or himself. The translation of al-Isra' (17: 33), reads: "And do not kill the soul which Allah has forbidden (to kill), except with one (reason) that is true".

- Protecting the intellect $(a l-A q l)$ What distinguishes humans from animals is the intellect, therefore we are obliged to take care and protect it. Islam advises us to seek Knowledge to the ends of the world and forbids us to corrupt our minds, such as drinking alcohol.

- Protect the family / descendants ( $a l-I r d)$ take care of the descendants by marrying religiously and politely. Having a child out of wedlock, for example, will affect inheritance and chaos in a family with unclear child status, which needs to be proven with blood test.

- Protecting wealth/property (al-Mal), wealth or property is very important and valuable, but Islam, forbids us to get our property illegally, by taking other people's property by stealing or damaging. As the voice of surah al-Baqarah 2: 188: "And let not some of you devour the property of others among you in a wrong way".

The above five important points are derived from the shariah as the essence of human existence. Therefore, all layers of society should protect it, because otherwise human life in the world will be chaotic, cruel, poor and suffering, both in this world and in the hereafter.

\section{b. Hajiyyat}

The importance that human beings need in order to facilitate them and get rid of the narrowness that leads to difficulties and hardships in its absence. While its absence is not to bring defects in human life in comparison to the absence of al-daruriyat, but it will lead to difficulties in their lives. For example, some convenience (rukhsah) such as qasar and jama' prayers are prescribed for people who are travellers, to fast during Ramadan is not an 
obligation for people who are sick or travellers, performing prayers in a sitting position for people who are unable to stand, wiping khuf instead of washing feet when ablution, traveling and others.

\section{c. Tahsiniyyat}

Interest that requires one to adhere to good morals and noble character. The absence of altahsiniyat does not lead to the difficulties of human life as the absence of al-daruriyat and alhajiyyat, but it leads to a life that is not good in the eyes of the rational people. For example, Islam requires purification and covering the aurat in prayer, wearing fragrance while in the mosque and in public gatherings and others. In the matter of muamalat, Islam forbids any transaction that causes harm such as drugs, faeces, carcasses and so on. Similarly, Islam forbids the sale and purchase of other people's purchases and also the proposal for the proposal of others. In custom, Islam teaches the manners of eating and drinking, forbids eating vile and harmful food, just as Islam forbids exceeding the limits in eating and drinking and dressing and others.

\section{Formation of Maqasid Shariah}

In general, the formation of maqasid shariah begins with the law which is grouped into two broad categories. In the first subcategory, al-Syatibi discusses God's true intention in setting the law, in this case to protect human welfare (both secular and religious), as long as it is recognized by the principles of daruriyyat, hajiyyat, tahsiniyyat. In the second subcategory, al-Syatibi discusses God's purpose in making the shariah. Therefore, the shariah must be understood by ordinary people and cannot be understood by certain circles. So, the purpose is for the believers to know the law of God, because if they do not understand the language used by the law, then they are ignoring the law itself. The third subcategory tends to be easy to understand, and in most of the writing of this section it is said that in this law it requires Muslims to abide by the rules as a whole (Al-Qardhawi, 1996; Naim, 2003).

That is how intentional violations of the law should be punished according to the type of violation. It can also be stated that there is an action which in practice violates the law even if the intention is not meant. It seems that the human will in Al-Syatibi's discourse has so far been explained using Sufism as an example. But here he continues his discussion of the tactics of law (biyal) in the close relationship, or not, between the will of God and the will of man. And it is also explained that the target this time is to move from the Sufis to a group of jurists who according to him have acted excessively in disregarding the law, perhaps in conveying his criticism to the jurists. He argues that the main purpose of biyal is to prevent the enactment of a law or to replace it with another provision so that there are no consequences not desired by the law.

\section{Maqasid Shariah as a Paradigm in the Implementation of Financial Assistance}

Generally, maqasid shariah can be defined as the purpose or objective of shariah which aims to produce maslahah or goodness to human beings while preventing and eradicating harm or mafsadah to human beings at the same time. This maslahah and mafsadah are not only limited to good and harm in this world but also includes its importance in the hereafter.

Majid (2012) concludes that the concepts of maslahah and mafsadah that exist in maintaining these five shariah objectives include the following elements: 
Table 1: The concept of maslahah and mafsadah

\begin{tabular}{ll}
\hline \multicolumn{1}{c}{ Maslahah } & \multicolumn{1}{c}{ Mafsadah } \\
\hline $\begin{array}{l}\text { Reasons and ways to obtain the good } \\
\text { of the hereafter }\end{array}$ & $\begin{array}{l}\text { Causes and ways to avoid the } \\
\text { evils of the hereafter }\end{array}$ \\
\hline $\begin{array}{l}\text { Reasons and ways to obtain the good } \\
\text { of the world }\end{array}$ & $\begin{array}{l}\text { Causes and ways to avoid the } \\
\text { evils of the world }\end{array}$ \\
\hline $\begin{array}{l}\text { Every delicacy and pleasure whether } \\
\text { physically, } \\
\text { intellectually or spiritually as a fact of } \\
\text { goodness }\end{array}$ & $\begin{array}{l}\text { Every misery whether physically, } \\
\text { spychologically, intellectually or } \\
\text { spitually as a fact of ugliness }\end{array}$ \\
\hline
\end{tabular}

Al-Shatibi asserts that the goodness gained through the goal of obtaining maslahah in the maqasid shariah is the goodness that is able to provide survival, rather than producing mafsadah as a side effect and subsequently causing the collapse of that life (Majid, 2012).

As stated earlier that the purpose of shariah statement is to achieve reward and avoid danger in two different dimensions of time namely in this world and the hereafter. This means that all aspects of Islamic teachings must lead to the achievement of this goal, including in the implementation of financial assistance. Therefore, the implementation of financial assistance must be able to be a signpost and a way out to overcome problems in the implementation of financial assistance.

Rules in shariah are closely related to various dimensions of aspects of human behaviour. The financial assistance aspect is just one of a series of human behaviours. Previous discussions on the theory of maqasid shariah inevitably have implications for the implementation of financial assistance. Compiling and explaining the implications of maqasid shariah in the implementation of financial assistance is a very difficult challenge and task, which needs to be implemented to help those in need.

Humans have desires in their lives that are material and spiritual in nature. Therefore, in order to fulfil the basis of this fact, the use of resources and wealth on earth must have a certain measure in order to achieve human desires on earth. Mannan (1980) has outlined several principles that guide the use of truth or right, cleanliness or purity, spirituality or morality, simplicity and usefulness and benefit. The method of use in financial aid is focused on the priority for each use that will be done by the recipient of the aid. For example, recipients of financial assistance can decide on their preferences in the use of such financial assistance.

In general, social welfare are community activities carried out aimed at upgrading and helping towards the welfare and goodness of human beings in their lives. For example, the poverty of a family can be overcome with social welfare measures to remove these poor families from the hardships and constraints in life. Social virtue in Islam is comprehensive in nature covering individuals and society. This virtue is achieved when individuals and society adhere to the norms of a virtuous life that are fundamental to the humanity and civilization of society (Hassan, 1995).

In the maqasid shariah paradigm, the function of social welfare is based on the concept of maslahah which is the basis for making any decision in the economy. In other words, the foundation of the formation of Islamic social welfare function is strong and consistent 
throughout the ages and is suitably implemented in all places and nations. For the function of consumption in Islam based on the concept of maslahah the use of goods starts with daruriyyat goods, followed by hajjiyat and kamaliyyat and it depends on the income of the individual. In addition to individual disposable income, the use of certain goods, such as daruriyyat goods in the economy by the less fortunate can be provided by certain parties such as the government to achieve socio-economic welfare. Consumption should be based on the principles of right or truth, cleanliness or holiness, spirituality or morality, simplicity, usefulness and benefit (Mannan, 1980). Consumption is defined as the expenditure of a Muslim individual based on shariah principles.

Similarly, in the context of income and wealth distribution as outlined by Islam is integrated which includes the distribution of wealth before the production process, distribution after the production process and finally the distribution of wealth to those not involved in the production process such as the sick, disabled and others. This final distribution process is also called the redistribution of wealth to the community through, among others, the institution of zakat and sadaqah to achieve social and economic welfare functions to the society, and for the wealth to not be among the rich only. This form of wealth distribution differs directly from the concept of wealth and income distribution in the conventional economic framework because in this theory it does not directly discuss such distribution before the process of production or redistribution of wealth.

Based on the discussion of maqasid shariah, which has been discussed earlier shows that the paradigm of maqasid shariah is as an achievement of Muslims in the field of spirituality and material based on religion and shariah. Therefore, the implementation of financial assistance through the paradigm of maqasid shariah is able to make the implementation of such assistance towards better direction and has a clear goal. In addition, it is also able to help provide pleasure and make the group that receives the assistance to strive in getting better in life the help to strive in getting something for a better life. The basis of maqasid shariah which involves aspects of daruriyyat, hajiyyat and tahsiniyyat should be the core in the implementation of financial assistance in Malaysia so that it becomes clearer and able to achieve the goals for the implementation of financial assistance.

\section{Conclusion}

The discussion of the maqasid shariah paradigm in the implementation of financial assistance as the purpose behind the existence of a network of rules has been outlined by Allah SWT. The purpose is to benefit and prevent harm to humans. All aspects in the life of the Muslim individual must lead to the attainment of benefits as required in the maqasid shariah. Maqasid shariah is the purpose or intent of shariah. Among the scholars there are three different opinions. The first is the opinion of Ibn Taimiyyah who stated that the purpose of Allah SWT's revelation about the system in Islamic law or shariah is to achieve justice (al-adl). The second opinion states that the purpose of shariah is to achieve eternal happiness (sa'adah haqiqiyah). The third opinion is the opinion of Imam al-Ghazali who said that the purpose of shariah is to achieve and realize the benefits and all the interests (maslahah) that are numerous for all mankind in this world. Based on this analysis, it is important for the implementation of financial assistance to take into account of each distribution and use of the assistance that will be distributed to those that are eligible to receive the assistance so that the goals and objectives of the financial assistance implementation is achieved. Each 
basic thing that wanted to be implemented should be started with better foundations such as a discussion regarding the paradigm of maqasid shariah.

\section{Acknowledgement}

Special thanks to Universiti Sains Malaysia for making it possible for this paper to be written. This paper is part of the research entitled Model Eko-Politinomik Islam (Islamic EcoPolitinomics Model) [203/CISDEV/671711] and conducted with assistance from the Fundamental Research Grant Scheme (FRGS) [FRGS/1/2018/SSI12/USM/02/1] by the Ministry of Higher Education Malaysia.

\section{Corresponding Author}

Wan Norhaniza Wan Hasan

Centre for Islamic Development Management Studies (ISDEV), Universiti Sains Malaysia, 11800 USM, Penang.

Email:wanhaniza@usm.my

\section{References}

Al-Qardhawi, Y. (1996). Fi figh al-awlawiyat-dirasat jadidah fi dow'i al-Quran wa al-Sunnah. Kaherah: Maktabah Wahbah.

Al-Qardhawi, Y. (1998), as-Siyasah asy-Syar'iyyah fi Dhau'i Nushuh asy-Syari'ah wa Maqashidiha. Kairo: Maktabah Wahbah.

Bowen, G. A. (2009). Document analysis as a qualitative research method. Qualitative research journal, 9(2), 27-40.

David, M., \& Sutton, C. D. (2011). Social research: an introduction: SAGE Publications.

EPU. (2015). The Eleventh Malaysia Plan 2016-2020. Putrajaya: EPU, Jabatan Perdana Menteri Malaysia.

Hassan, N. M. N. (1995). Islam-Kedudukan dan Peranan Sektor Awam dan Swasta, Kuala Lumpur: IKIM, p. 36.

Hennink, M., Hutter, I., \& Bailey, A. (2010). Qualitative research methods: Sage.

JKM (Jabatan Kebajikan Masyarakat). (2021). Welfare Assistance Scheme. https://www.jkm.gov.my/jkm/index.php?r=portal/left\&id=NzFHMnJLSWxoQytmM3 RscmUvMVdWZz09.

Majid, M. Z. A. (2012). Maqasid al-Shariah: Satu pengenalan. In. Mahmood Zuhdi Abdul Majid, Mek Wok Mahmud \& Akhtarzaite Abdul Aziz (ed.), Maqasid al-Syariah. Kuala Lumpur: IIUM Press. 1-50.

Mannan, M. A. (1980). Islamic Economics Theory and Practice. Delhi: Idarah-i Adabiyat-i.

MOF (Ministry of Finance) (2018). UCAPAN BAJET TAHUN 2017. http://www.treasury.gov.my/pdf/bajet/ucapan/ub17.pdf.

Naim, A. M. (2003). Maqasid Syariah dan Pemikiran Pengurusan Islam. Kedah: Penerbit UUM.

Nyang, S. S. (1976). "The Islamic State and Economic Development: A Theoretical Analysis", Islamic Culture, 50, 11.

Said, N. A., \& Khairuldin. (2017). Freedom of Speech in Islam and its Connection with Street Demonstrations. International Journal of Academic Research in Business and Social Sciences, 7(4), 122-129.

Khairuldin, Embong, A. H., Anas, W. N. I. W. N., Ismail, D., Ibrahim, I., \& Fauzi, N. (2017). Freedom of Speech: A Comparative Study between Islam and Malaysian Laws. 
International Journal of Academic Research in Business and Social Sciences, 7(2), 2222-6990.

Ibrahim, I., \& Khairuldin. (2017). Fatwa as a Medium Da'wah: Studies on the Role of Mufti as a Preacher. International Journal of Academic Research in Business and Social Sciences, 7(4), 10-18.

PEMANDU (Performance Management Delivery Unit). (2013). Annual Report 2012. http://www.pemandu.gov.my/gtp/annualreport2012/.

Sadeq, A. H. M. (1987). Economic growth in an Islamic economy. Proceeding International Seminar on Islamic Economics.

Sadeq, A. H. M. (1996). Muslim and Economic Development: Present State and Future Potentials. In Kadir H. Din (Ed.) Development and the Muslims (47-60). Selangor: UKM.

Tracy, S. J. (2013). Qualitative research methods. UK: Wiley-Blackwell. 